\title{
Governmental duty of care for disaster-related science diplomacy
}

\begin{abstract}
Purpose: This paper presents a first exploration of governmental duty of care towards scientists involved in science diplomacy by focusing on disaster research.

Design/methodology/approach: The method is a conceptual exploration, using specific case studies and potential scenarios within theories and practices of science diplomacy and duty of care, to raise questions and to suggest policy recommendations for government. The focus on disaster research links the analysis to disaster diplomacy, namely how and why disasterrelated activities (in this case, science) do and do not influence peace and conflict.
\end{abstract}

Findings: From examining case studies of, and outputs and outcomes from, disaster-related science diplomacy, governments need to consider duty of care issues in advance and develop a science diplomacy strategy, rather than responding after the fact or developing policy ad hoc.

Practical implications: Policy recommendations are provided to try to ensure that governments avoid simply reacting after a crisis, instead being ready for a situation before it arises and drawing on others' experience to improve their own actions.

Social implications: Improved interaction between science and society is discussed in the context of diplomacy, especially for disaster-related activities.

Originality/value: Governmental duty of care has not before been applied to science diplomacy. The focus on disaster-related science further provides a comparatively new dimension for science diplomacy.

\section{Keywords}

disaster diplomacy, duty of care, science diplomacy

\section{Article classification}

General review

\section{Connecting science diplomacy, duty of care, and disaster-related research}

This paper presents a first exploration of governmental duty of care towards scientists conducting science diplomacy by focusing on disaster research. The exploration is conceptual, with this section providing basic concepts and illustrating them with scenarios. Then, examples of disaster-related science diplomacy are provided, leading to discussion of outputs and outcomes alongside the possible duty of care situations which could arise for governments. The questions raised lead to policy implications.

Diplomacy here is defined as peaceful interactions amongst representatives from different political jurisdictions. These interactions could be formal, such as in the United Nations (UN) or official bilateral meetings, or informal, away from recorded minutes and rule-based proceedings. Diplomacy with this definition occurs beyond sovereign states and is not 
necessarily confined to representatives of their jurisdictions, instead merely being from different political jurisdictions. Non-sovereign territories, supranational entities such as the European Union (EU), and subnational jurisdictions such as provinces and municipalities are involved in diplomatic endeavours, with examples being trade and environmental agreements, arts and culture exchanges, and post-disaster assistance. Diplomatic processes outside of sovereign state representatives are termed para-diplomacy, proto-diplomacy, and microdiplomacy (Baldacchino and Milne, 2009; Duchacek et al., 1998; Tavares, 2009).

Whilst representatives involved in diplomacy have traditionally been from governments, diplomacy is also enacted by many different parties including celebrities, media, arts organisations, religious groups, sports teams, and ordinary people (Diamond and McDonald, 1993; Kurbalija and Katrandjiev, 2006; Sending et al., 2011). Science and scientists can also be involved in diplomacy. Science refers to formalised investigations for the purpose of generating new and original knowledge, thus covering all disciplines including physics, anthropology, law, ecology, geography, engineering, education, medicine, international relations, chemistry, and political science. Science diplomacy is thus peaceful interactions across political jurisdictions for purposes related to knowledge production, typically (but not exclusively) considering political jurisdictions with some form of conflict which might or might not be violent. It could be enacted by scientists or for scientific endeavours such as research projects, publications, and conferences. The process of science diplomacy has long been pursued across numerous fields, but scholarship covering the term and concept has only more recently and more formally been developing as a field of study, including with detailed empirical examples (e.g. Davis and Patman, 2015; Tonami, 2016).

Within science diplomacy's remit, scientists sometimes accept formal diplomatic posts or pursue formal diplomacy. Edward Jenner from England became so respected for introducing the smallpox vaccine in 1796 that he later mediated prisoner exchanges between France and England. From 1954-1969, Henry Kissinger was an academic staff member at Harvard University, becoming Assistant to the President for National Security Affairs and, from 19731977, US Secretary of State, the country's top diplomat. Condoleezza Rice was a Professor at Stanford from 1981-1993 before becoming the university's Provost from 1993-1999 and then US Secretary of State from 2005-2009. Vaira Vīke-Freiberga was a Professor at the University of Montréal from 1965-1998 before becoming President of Latvia from 19992007.

Nevertheless, science diplomacy usually occurs via actively researching scientists who might or might not be interested in the diplomatic outcomes of their science. The Pugwash Conferences on Science and World Affairs (http://www.pugwash.org) are a deliberate attempt to use science for the diplomatic end of eliminating weapons of mass destruction including nuclear weapons.

Eliminating weapons of mass destruction is an example of disaster risk reduction. Disasterrelated research has shown that the root causes of disasters, and the process of disaster risk reduction, are inevitably political (Cuny, 1983; Hewitt, 1983, 1997; Lewis, 1999; Wisner et al., 2004). One dimension of the disasters-politics nexus is disaster diplomacy, examining how and why disaster-related activities - before, during, and after disasters - do and do not influence peace and conflict (Kelman, 2012, 2016). Disaster diplomacy has variously been defined as a concept, a process, a field of study, or a diplomatic subset, with Yim et al. (2009) providing apt critiques of its presentation. 
Here, disaster diplomacy focuses on processes of and investigations about disaster-related activities influencing diplomacy, thereby encompassing processes of both science and diplomacy while covering research, policy, and practice. The process is specifically unidirectional, from disaster-related activities to diplomacy, rather than the other way around which is effectively the truism of politics influencing disaster-related activities (Cuny, 1983; Hewitt, 1983, 1997; Lewis, 1999; Wisner et al., 2004). Disaster diplomacy research and application cover the combination of the diplomacy required for reducing disaster risk and the diplomacy involved in effecting peace and conflict, Hence, disaster diplomacy is a suitable focus for studying science diplomacy since scientists and science are frequently involved in all such activities. Few publications have thus far touched upon the science diplomacy implications, or lack thereof, emerging from disaster diplomacy.

One science diplomacy discussion for disaster research has been Cuban and American scientists collaborating on hurricane monitoring, El Niño impacts, and climate variability and trends during Fidel Castro's leadership of Cuba (Glantz, 2000). The cooperation was successful at a scientific level, but had no discernible impact on political or diplomatic processes, with Cuba-US relations eventually thawing due to a change in political leadership in Cuba. The scientific collaboration might even have succeeded because politicians were not aware of it and so could not interfere with it - or politicians might have pretended not to be aware of it. That is, the scientific interaction remained at the scientific level without science diplomacy resulting. The same is true for more recent calls for Cuba-US scientific collaboration on disease and medicine (Fink et al., 2014), earthquakes (Yeats, 2014), and wider environmental research (Boom, 2012) which seek joint science rather than science diplomacy.

Had the political leaders been aware of the scientific interaction, or openly acknowledged it happening, prospects exist for the scientists ending up in legal trouble. Americans wishing to visit Cuba under Fidel Castro's reign faced severe travel restrictions. Many, including scientists, circumvented the rules by travelling to Cuba via a location outside the US and, upon entering Cuba, requesting that their passport not be stamped. The US government could have prosecuted Americans doing so, but did not.

Meanwhile, Fidel Castro ran Cuba as a totalitarian dictatorship which was long criticised for human rights abuses, as documented independently from the US government's attempts to discredit Fidel Castro (Platt, 1988). Had the Cuban government decided, any Cuban scientist working with Americans could have been removed from their job, imprisoned, and potentially tortured. An American scientist visiting Cuba could have suffered a similar fate-as shown by Alan Gross, a USAID contractor arrested in Cuba for spying despite entering the country openly to install internet equipment (Leogrande, 2015).

In such instances, what actions should governments take? The US government could take the stance that they owe no support to any American or Cuban scientists arrested in Cuba as a result of US-Cuba scientific cooperation. This issue relates to the duty of care of a government to scientists involved in science diplomacy, with the focus here being disaster research and hence disaster diplomacy.

The duty of care to prevent disasters has long been studied in law (Morison, 1948) and in its moral sense apart from legal requirements (Kenyon, 1996). For disasters, a clear duty of care has been placed on sovereign governments to protect its citizens or to accept external assistance for doing so (Davies, 2010), with such discussions covering both legal and moral 
aspects. Yet for epidemic disasters, "duty of care" has been lambasted as "at best, too vague and, at worst, ethically dangerous...Duty of care is neither fixed nor absolute but heavily dependent on context" (Sokol, 2006, p. 1238). This statement is further shown by the duty of care literature which rarely provides a consistent definition for the term and which focuses on discussions of operational actions, with disaster-linked scenarios including humanitarian interventions (Arbour, 2008) and emergency medicine (Schultz, 2012).

The question of duty of care of a government to its scientists working outside their country is not prominent in the literature regarding morals or legalities, actual or speculated. There is also ambiguity regarding whether the priority is the legal or moral component of duty of care - or both in combination, irrespective of proportions selected. Here, to embrace the full range of possibilities from the literature, duty of care is used in its moral sense which does not preclude, but moves beyond, purely legal dimensions. The next section explores case studies and scenarios related to science diplomacy for disaster research.

\section{Case studies and scenarios}

This section describes examples of science diplomacy for disaster research, including outputs and outcomes, while exploring possible scenarios involving duty of care of the scientists' governments to them.

\section{Examples of science diplomacy for disaster research}

In March 2012, the American Association for the Advancement of Science began a quarterly publication entitled Science \& Diplomacy (http://www.sciencediplomacy.org). In the nineteen issues published up to September 2016 with a total of 115 articles, the word "disaster" is mentioned in sixteen articles (in one article, just in the references) but no articles discuss "duty of care". The articles mentioning "disaster" balance:

- natural and non-natural hazards;

- before, during, and after disasters;

- disasters as a separate scientific topic and disasters integrated with other science such as development and health; and

- the hazard and vulnerability components of disaster risk.

When searching for specific hazard-related terms, such as "climate" and "earthquake", many other articles are listed. Searches for "vulnerability" and "vulnerable" yield no new disasterrelated articles, but other articles appear using the words in different contexts. Consequently, a wide range of science diplomacy for disaster research exists, although no disaster diplomacy outcomes are indicated. This gamut of examples is reflected across other literature, although the work is infrequently identified directly as science diplomacy.

Since the 1990s, the World Meteorological Organization has promoted Climate Outlook Forums in most regions of the world in which scientists and users collaborate to generate a consensus on climate projections for the coming season (http://public.wmo.int/en/ourmandate/climate/regional-climate-outlook-products). Some of the climate outlook forums involve countries in conflict, such as the North Eurasia Climate Outlook Forum including Armenia and Azerbaijan; the Caribbean Climate Outlook Forum including American and Cuban scientists; the Greater Horn of Africa Climate Outlook Forum including Eritrea and Ethiopia; and the South Asian Climate Outlook Forum including Afghanistan, India, and Pakistan. Activities include developing probabilistic climate outlooks, discussing potential implications for different sectors, training for using the outlooks, and applying 
communication strategies. An evaluation of climate outlook forums in Africa indicated the importance of connecting all the activities to avoid probabilistic forecasts being taken as set predictions, to maintain trust, and to translate the climate outlooks into on-the-ground support for livelihoods decisions (Patt, 2007). Diplomatic aims and outcomes including disaster diplomacy are not present, suggesting that the climate outlook forums are for science only.

Similarly, despite Iran's isolation from many other countries, including the UK and the US, extensive scientific activities occur jointly. The British Council sponsored events in Iran in 2007 and 2016, with the latter connecting to disasters by studying epidemics and global health including the Zika virus. Between 2005 and 2017, Iran has held eight Integrated Disaster Management (INDM) Conferences, typically inviting UK scientists as keynote speakers.

Despite this science diplomacy, disaster diplomacy has not manifested and Iran has a difficult record with some other scientists. Canadian-Iranian social anthropologist Homa Hoodfar from Concordia University was arrested in Iran in June 2016 after being denied permission to leave the country. She was released in September 2016. Iranian Omid Kokabee was studying for his $\mathrm{PhD}$ in laser physics at the University of Texas when he was arrested in Iran in January 2011 while visiting his family, allegedly for giving secrets to the US government. He stated that it was because he refused to work on Iran's nuclear programme. He was released in August 2016. Several Iranian nuclear scientists have been murdered in Iran, with outside scientists condemning the killings and stating instead that science should and could be used for peace (Hecker and Milani, 2015).

In such contexts, duty of care dilemmas emerge. If a scientist from an ostensibly neutral country such as Austria or Norway travels to Iran to support the country's nuclear programme, what duty of care would the government owe to their citizen in case of arrest in Iran? Would it matter if the scientist states that they were supporting the nuclear power programme, the nuclear weapons programme, both, or neither? If the scientist travels for an international conference on nuclear science, rather than working in a lab alongside Iranian counterparts, would it make a difference? For answering such questions, it is clear that, on paper, the country of nationality owes as much consular assistance as feasible to their citizens, but this principle provides extensive leeway for the parties involved to decide according to circumstances. Iran does not recognise dual citizenship, so Hoodfar was denied access to Canadian diplomats. Canada's government nonetheless pressured Iran over her detention, although how much real support was provided, publically or secretly, is disputed.

If Israel were the country in which the scientist from Norway or Austria is arrested, would duty of care change? Palestinian astrophysicist Imad al-Barghouti was arrested by Israel in 2014 and 2016 for allegedly anti-Israel comments. A Norwegian or Austrian scientist could easily make similar, or worse, public comments and then visit Israel for tourism, a conference, or collaboration with colleagues. Alternatively, the scientist might visit to assist Israel with its nuclear programme and/or to support Palestinian independence. If the scientist were arrested, the circumstances would influence public reaction and could impact the Norwegian or Austrian government's duty of care to the scientist.

Historical examples exist, such as the Cuba-US scientific collaboration under Fidel Castro's rule, mentioned earlier (Glantz, 2000). During the Cold War and during the USSR-to-Russia transition, one American climate scientist travelled to Moscow to research and publish with Soviet/Russian scientists on environmental disasters in the USSR (Glantz and Orlovsky, 1983; Glantz et al., 1993) despite continual censorship on these topics (Ziegler, 1990). Had 
the American scientist been arrested in the USSR or Russia, the US government would owe a duty of care, since the visits were legitimate and legal. Had an American scientist been arrested in Cuba, the duty of care of the US government to the scientist is less obvious, since the scientist would have been travelling to Cuba against US government advice and against American law.

This raises the question of a government's duty of care towards a scientist travelling to a location against their government's advice. In October 2016, the UK government advised against all travel in Eritrea within $25 \mathrm{~km}$ of the Ethiopian border and most travel in Ethiopia within $10 \mathrm{~km}$ of the Eritrean border. Nabro volcano sits in Eritrea adjacent to the Ethiopian border. Until it erupted in 2011 with seven fatalities and 12,000 evacuees, it had no known Holocene eruptions, so was classified as inactive (Clarisse et al., 2014; Goitom et al., 2015). For disaster response, collecting data on the volcano is paramount in order to analyse its potential behaviour. UK seismologists and volcanologists had been working in the area, including for cross-border work, building up a substantive baseline of knowledge and scientific contacts, permitting them to respond rapidly in 2011; in fact, one UK scientist was in Asmara at the time of the eruption (Goitom et al., 2015; Hammond, 2016). If Nabro erupted again while the area was under a UK travel warning, the UK scientists would consider travelling there to continue their work and would likely be invited there in order to do so. If they run into medical or political trouble, the UK government would need to consider carefully the government's duty of care to the scientists.

The Eritrea-Ethiopia border situation complements similar work by UK volcanologists and seismologists for Mount Paektu (Changbaishan / Baekdusan) which straddles the China-North Korea border. Paektu's eruption just over 1,000 years ago was one of the largest volcanic explosions in human history, so with the potential for further activity, North Korean scientists reached out to their UK counterparts for collaboration (Hammond, 2016; Stone, 2011, 2013). Persevering to overcome the challenges of securing government permission for cooperation, travel, and bringing equipment into North Korea through the international sanctions, the scientists continue to work together on analysing data from the monitoring network they set up and from the volcanic samples they acquired. In this instance, with full governmental cooperation on both sides and the travel being fully legal, the UK government should abide by their duty of care to the UK scientists if the scientists were injured or jailed in North Korea.

The experiences of UK volcanologists in Eritrea and North Korea led to five lessons for ensuring science diplomacy success: "1. Strong, clear science objectives; 2. Enthusiastic scientific partners; 3. Good, open communication; 4. Delivering on promises made (and therefore ensuring that commitments are realistic in the first place); and 5. Flexibility" (Hammond, 2016, p. 7). Security, safety, morality, and legality are not listed, perhaps under the assumption that those aspects are obvious or perhaps because the focus is directly and almost exclusively on the science, rather than seeking diplomatic or objectives simultaneously. In their articles on Eritrea and North Korea, the scientists label their work as being science diplomacy, yet the goals, actions, and outcomes are all described as being scientific, with little substance regarding diplomacy and no disaster diplomacy consequences mentioned.

One success factor might be the focus on physical science through examining environmental hazards, which is often presumed to be objective, neutral, and apolitical, even though it is not (Martin, 1979). The appearance of objectivity, neutrality, and lack of politics might permit the 
work to take place. By comparison, the root cause of disasters, the vulnerability part of the disaster risk equation, is political by definition, with policies and practices which create and perpetuate, or tackle and reduce, vulnerability often emerging due to political ideology (Hewitt, 1983; Wisner et al., 2004). The political nature of vulnerability research might stop science diplomacy and disaster diplomacy. Even though some of the joint studies for Cuba, Eritrea, and North Korea report vulnerability aspects, the research has neither collected data on the vulnerabilities present nor analysed the reasons for the vulnerabilities existing.

Meanwhile, detailed disaster vulnerability studies for Cuba (Aguirre, 2005; Sims and Vogelmann, 2002) and Mount Paektu (Choi et al., 2013; Yu et al., 2016) are not representative of science diplomacy, since the former are by only US-based scientists and the latter are by only South Korea based scientists. This situation does not denigrate the scientific work. It simply means that a potential gap remains in disaster-related science diplomacy of conducting joint, detailed analyses for identifying and redressing disaster vulnerabilities.

\section{Outputs and outcomes from scientists collaborating on disaster research}

The case studies of science diplomacy for disaster research led to definite outputs, with less clear outcomes. The outputs fall into the two typical categories of scientific outputs: publications and projects.

Publications are both peer-reviewed (such as journal papers and books, e.g. Glantz et al. (1993) and Goitum et al., (2015)) and non-peer-reviewed (such as news or newsletter articles, e.g. Glantz and Orlovsky (1983) and Stone $(2011,2013))$. Joint authorship by scientists from the countries involved is typical, such as North Korean and British scientists publishing on the volcanology of Mount Paektu with one China-based author (Kyong-Song et al., 2016). Another manner of publishing together for science diplomacy is editing, such as an American scientist editing books with chapters from a Cuban scientist covering Cuba dealing with El Niño and La Niña (Naranjo-Diaz, 2000, 2002).

Grant-based projects comprise the other main output category. Field work requires money for travel and equipment. Researchers sometimes need to be paid, such as doctoral student stipends, post-doctoral fellowships, or researcher time for institutes without full core financing. The work cited in the previous paragraph emerges from funded projects, with granting agencies including the United Nations Foundation and the Richard Lounsbery Foundation.

Outcomes are harder to delineate than outputs. Friendships, exchanges, and mutual learning and teaching resulted from the work cited here, facilitating the continuing science. Outcomes related to the effectiveness of the disaster-related activities and the consequences for diplomacy, namely disaster diplomacy, are almost absent. No spillover into US-Cuba cooperation was identified based on the science diplomacy. Instead, the two countries' rapprochement occurred because Cuba's leadership changed from Fidel Castro (Hershberg and LeoGrande, 2016). None of the collaborating Cuban or American scientists were involved in this political shift or appear to have influenced it.

Given that so many cross-border scientific collaborations happen due to an individual scientist choosing to work with another individual scientist, it might be that disaster diplomacy outcomes should be neither sought nor expected. Sometimes, scientists or their funders actively seek diplomatic outcomes, or state that they do. Sometimes the collaboration 
is for just the publication and project outputs. For instance, it might seem apposite to interpret the Norwegian Programme for Research Cooperation with China as part of mending relations with China following Chinese activist Liu Xiaobo being awarded the 2010 Nobel Peace Prize, but the programme began in 2009 (Research Council of Norway, 2009) following a 2007 government white paper (Government of Norway, 2007).

Even when research is directly funded by a government, science diplomacy is not necessarily sought. A Canadian engineer and an Iranian engineer might wish to collaborate on earthquake engineering, so they do, irrespective of their governments' relations. They might even be at the same institution, perhaps in a third country such as New Zealand, so collaboration happens, as in September 2016 when New Zealand's Ministry of Business, Innovation and Employment awarded two Auckland universities an earthquake engineering grant for staff members of Canadian and Iranian origins (University of Auckland, 2016). No intimation is given that disaster diplomacy was sought, nor do any researcher connections with their countries of origin or compatriots seem to be pertinent. Instead, it is a grant for research and application, judged on those merits alone.

The New Zealand government's duty of care to the scientists then becomes pertinent. Irrespective of the researchers' citizenship(s), they might consider travelling to Iran to present their work, such as at the Integrated Disaster Management Conference, and to collaborate with Tehran's International Institute of Earthquake Engineering and Seismology. If these scientists are treated like Hoodfar or Kokabee, then the New Zealand government would need to examine their duty of care to their scientists in the context of the scientists' passport countries, of Iran's view of the scientists' citizenships, and of the source of the grant money for travelling to Tehran. Considering that the grant was awarded for earthquake engineering technology which averts building collapse in an earthquake and which permits a quicker return to business afterwards, the New Zealand government might have a duty of care towards New Zealanders to ensure that the scientists can return to New Zealand and support retrofits of buildings.

If outputs and outcomes from disaster research are focused on science diplomacy or not, does the duty of care change? Even where influencing diplomacy is not intended, it can occur. Arctic research, including environmental monitoring, is suggested as reducing the chance of military conflict in the region (Goodsite et al., 2016). Conversely, American medical science diplomacy in Indonesia fomented conflict there through accusations of the Americans spying (Smith III, 2014). In the life sciences, one approach for both scientific education and research discusses diplomacy as being tacit, with collaborations naturally forming over scientific work and leading to wider acceptance and cooperation amongst countries which might not otherwise be prone to it.

An outcome from science can thus potentially be improved or worsened diplomacy, whether or not diplomatic influences are sought. None of the suggested science diplomacy successes are for disaster-related research, indicating that outcomes from disaster diplomacy via research might be less likely to succeed than other science diplomacy. It could also be that, thus far, less effort has been put into deliberately relating science diplomacy back to disaster diplomacy, either for research or for action. Such possible policy implications will be explored further in this paper's final section.

\section{Policy implications and conclusions}


Much science diplomacy for disaster research occurs inadvertently or at low diplomatic levels, with the research sometimes directly supported by governments and sometimes not. Tacit or passive science diplomacy is depicted most often in the case studies, with the research aiming for scientific rather than diplomatic outputs and outcomes; that is, disaster diplomacy is not sought from the science.

One policy could be for governments to push active science diplomacy by placing diplomatic expectations on scientists - or for scientists to choose to adopt active diplomatic roles. Kissinger, as a government-employed diplomat, was accorded a duty of care from the US government, as provided to any senior diplomat. Pugwash scientists might be employed by a government agency as scientists, but not as diplomats, so determining governmental duty of care is more intricate. Governments have multiple ways of using scientists for disaster diplomacy, officially and unofficially, but there are complex intricacies in science diplomacy beyond strict scientific endeavours.

For instance, Israeli and Iranian scientists were on the programme for the International Sociological Associations' World Congress of Sociology in Japan in 2014. They could be asked, formally or informally, by their governments to meet informally to discuss diplomacy or they might decide to do so themselves. They might each travel to another location such as Oslo to work with local collaborators and then meet, deliberately or inadvertently, with or without their governments' acquiescence. In all such instances, differences can arise in the intention and the expressed intention of the different parties involved. How well would the desire to establish or enhance relationships amongst learned societies match the desire to establish or enhance diplomatic relationships?

When trying to determine or match intentions, various opportunities arise and can be created. Using scientists as spies has a long history (Price, 2000; Schultz, 2012), so possibilities exist for scientists as secret diplomats. In such cases, a government should plan in advance its moral and legal duty of care to the scientists if the scientists encounter trouble, including considering any difference if the scientists' activities were within or outside of the scientists' research expertise or remit from their government. Examples are advising dissidents, climbing a mountain or building to take photos, and placing monitoring equipment.

Scientists are willing to be activists for disaster topics. Jim Hansen, one of the contemporary leaders of climate change research who was employed at the US government agency NASA (National Aeronautics and Space Administration) until his retirement in 2013, was arrested outside the White House in 2011 for protesting against a fossil fuel pipeline which, Hansen believes, contributes to environmental destruction (Bulletin of the Atomic Scientists, 2013). The arrest occurred in Hansen's own country, but the pipeline originates in Alberta's Tar Sands. If Hansen were arrested in Ottawa, what would be the US government's duty of care towards him? If a US government-employed scientist were arrested for protesting against climate change in countries less friendly than Canada towards the US, such as India or Iran, what would be the US government's duty of care towards the scientist? Activism or disaster diplomacy could be supported (or opposed) by the US government or accepted (or opposed) as part of the role of being a US government scientist.

In the above scenarios, from being a secret diplomat to a public activist, if the scientist's government encourages or organises the non-scientific activities, then a further duty of care decision is how much the government should admit knowing. As described above, Cuba-US scientific collaboration for disaster-related research was successful because the US 
government was (or pretended to be) ignorant about it. A government could similarly pretend to be entirely unaware of any scientist who is given disaster diplomacy or activist tasks.

Moreover, governments are not homogeneous entities. One department or civil servant could support a specific science diplomacy activity for disaster research, or science-based disaster diplomacy, while another department or civil servant opposes it. Politicians come from different parties and ideologies, leading to varying views of permissible engagement with other countries.

Scientists need to recognise that inaction or non-interference from their own government is not the same as their own government being ignorant of or uncaring about the scientist's activities. Governments need to consider duty of care issues in advance and to develop a science diplomacy strategy, rather than responding after the fact or developing policy ad hoc. Extended exploration of science diplomacy frameworks and categories would be needed contributions, especially continuing empirical testing of science diplomacy frameworks (see also Vanc and Fitzpatrick, 2016).

As one example of work on frameworks, USC Center on Public Diplomacy (2010, pp. 11-16) reports on a keynote given by Vaughan Turekian on "Science Diplomacy and the Prevention of Conflict". It is reported that he delineates three science diplomacy categories. First, "science in diplomacy" is about researching diplomacy, global issues, and foreign policies. Second, "diplomacy for science" refers to scientists requesting diplomatic assistance to carry out science. Third, "science for diplomacy" is suggested as being the core meaning of science diplomacy, namely "international science cooperation" (p. 12). These descriptions are rather general and do not include a potential fourth category of diplomacy in science, in which the scientific process or scientists are used for enacting diplomacy, as described above. These four categories clearly overlap and lead to specific actions, some described by Turekian in USC Center on Public Diplomacy (2010), such as personnel and data exchanges. Consequently, these points provide a useful baseline to begin discussions on a framework for analysing science diplomacy which should be a priority for a research agenda.

Another major element of a research agenda would be seeking examples (i) where science diplomacy for disaster-related activities has resulted in new diplomatic gains or new conflict and (ii) where duty of care-morally, legally, or both-was deliberately enacted to support scientists involved in disaster diplomacy, deliberately or inadvertently. As shown by this paper, the evidence thus far tends to affirm the current disaster diplomacy conclusions that disaster-related activities, including science, sometimes catalyse existing diplomatic and conflict processes, but do not create new such endeavours. The evidence also suggests that science diplomacy is rarely considered regarding duty of care to scientists involved in disaster diplomacy. An unambiguous counterexample would overturn some of these conclusions, reinforcing the need for further empirical research (see also Vanc and Fitzpatrick, 2016).

Calls for education and training on science diplomacy for professionals and generalists are also poignant (Turekian and Wang, 2014). These calls suggest the importance of a research agenda on (i) curriculum content and form; (ii) expected impacts of education and training, followed by monitoring of the actual impacts; and (iii) the potential duty of care of the educators and trainers to the students and trainees, before, during, and after any education and training. 
Science, diplomacy, disaster-related activities, and duty of care each involves multiple parties engaging in various actions, leading to complexities regarding their interactions and theorisations of fractal characteristics including for crises (Bjola, 2015). As with disasterrelated activities including disaster diplomacy, the key for duty of care for disaster-related science diplomacy is planning and preparing in advance. Much more work is needed to make this overarching, generic suggestion useable for specific situations.

\section{References}

Aguirre, B.E. (2005), “Cuba's Disaster Management Model: Should It Be Emulated?", International Journal of Mass Emergencies and Disasters, Vol. 23 No. 3, pp. 55-71.

Arbour, L. (2008), "The responsibility to protect as a duty of care in international law and practice", Review of International Studies, Vol. 34, pp. 445-458.

Baldacchino, G. and Milne, D. (Eds.) (2009), The Case for Non-sovereignty: Lessons from Sub-national Island Jurisdictions, Routledge, London.

Bjola, C. (2015), "Diplomacy as World Disclosure: A Fractal Theory of Crisis Management", British Journal of Politics and International Relations, Vol. 2015, pp. 1-18.

Boom, B.M. (2012), "Biodiversity without Borders: Advancing U.S.-Cuba Cooperation through Environmental Research", Science \& Diplomacy, Vol. 1 No. 3, http://www.sciencediplomacy.org/article/2012/biodiversity-without-borders

Bulletin of the Atomic Scientists (2013), "James Hansen: Taking heat for decades", Bulletin of the Atomic Scientists, Vol. 69 No. 4, pp. 1-8.

Choi, E.-K., Kim, S.-W., Lee, Y.-C., Lee, K.-H., and Kim, I.-S. (2013), "Analyzing the Disaster Vulnerability of Mt. Baekdusan Area Using Terrain Factors", Journal of the Korean earth science society, Vol. 34 No. 7, pp. 605-614.

Clarisse, L., Coheur, P.-F., Theys, N., Hurtmans, D., and Clerbaux, C. (2014), "The 2011 Nabro eruption, a $\mathrm{SO}_{2}$ plume height analysis using IASI measurements", Atmospheric Chemistry and Physics, Vol. 14, pp. 3095-3111.

Cuny, F. (1983), Disaster and Development, Oxford University Press, New York, NY.

Davies, S.E. (2010) "Is There an International Duty to Protect Persons in the Event of an Epidemic?", Global Health Governance, Vol. 3 No. 2, http://www.ghgj.org/Davies3.2\%20International.htm

Davis, L.S. and Patman, R.G., (2015) Science Diplomacy: New Day or False Dawn? World Scientific, Singapore.

Diamond, L. and McDonald, J. (1993) Multi-Track Diplomacy: A Systems Approach to Peace, Institute for Multi-Track Diplomacy, Washington, DC. 
Duchacek, I., Latouche, D., and Stevenson, G. (eds.) (1988), Perforated Sovereignties and International Relations: Trans-Sovereign Contacts of sub-national Governments, Greenwood Press, Westport, CT.

Goodsite, M.E., Bertelsen, R.G., Pertoldi-Bianchi, S.C., Ren, J., van der Watt, L.Z., and Johannsson, H, (2016), "The role of science diplomacy: a historical development and international legal framework of arctic research stations under conditions of climate change, post-cold war geopolitics and globalization/power transition", Journal of Environmental Studies and Sciences, Vol. 6 No. 4, pp. 645-661.

Fink, G.R., Leshner, A.I., and Turekian, V.C. (2014) "Science diplomacy with Cuba", Science, Vol. 344 No. 6188, p. 1065.

Glantz, M.H. (2000), "Climate-related disaster diplomacy: a US-Cuban case study", Cambridge Review of International Affairs, Vol. XIV No. 1, pp. 233-253.

Glantz, M.H. and Orlovsky, N.S. (1983), "Desertification: A review of the concept", Desertification Control Bulletin, Vol. 9, pp. 15-22.

Glantz, M.H., Rubinstein, A.Z., and Zonn, I. (1993), "Tragedy in the Aral Sea basin: Looking back to plan ahead?", Global Environmental Change, Vol. 3 No. 2, pp. 174-198.

Goitom, B., Oppenheimer, C., Hammond, J.O.S., Grandin, R., Barnie, T., Donovan, A., Ogubazghi, G., Yohannes, E., Kibrom, G., Kendall, J.-M., Carn, S.A., Fee, D., Sealing, C., Keir, D., Ayele, A., Blundy, J., Hamlyn, J., Wright, T., and Berhe, S. (2015), "First recorded eruption of Nabro volcano, Eritrea, 2011", Bulletin of Volcanology, Vol. 77 No. 10, article 85.

Government of Norway (2007) Regjeringens Kina-strategi, Utenriksdepartementet, Oslo.

Hammond, J. (2016), "Understanding Volcanoes in Isolated Locations: Engaging Diplomacy for Science", Science \& Diplomacy, Vol. 5 No. 1 , http://www.sciencediplomacy.org/perspective/2016/understanding-volcanoes-in-isolatedlocations

Hecker, S.S. and Milani, A. (2015), "Ending the assassination and oppression of Iranian nuclear scientists", Bulletin of the Atomic Scientists, Vol. 71 No. 1, pp. 46-52.

Hershberg, E. and LeoGrande, W.M. (Eds.) (2016), A New Chapter in US-Cuba Relations: Social, Political, and Economic Implications, Palgrave MacMillan, New York, NY.

Hewitt, K. (1983), Interpretations of Calamity from the Viewpoint of Human Ecology, Allen \& Urwin, Boston, MA.

Hewitt, K. (1997), Regions of Risk: A geographical introduction to disaster, Addison Wesley Longman, New York, NY.

Hotez, P.J. (2001), “Vaccine Diplomacy”, Foreign Policy, May/June, pp. 68-69.

Kelman, I. (2012), Disaster Diplomacy: How Disasters Affect Peace and Conflict, Routledge, Abingdon. 
Kelman, I. (2016), "Catastrophe and Conflict: Disaster Diplomacy and Its Foreign Policy Implications", Brill Research Perspectives in Diplomacy and Foreign Policy, Vol. 1 No. 1, pp. 1-76.

Kenyon, A. (1996), "FOCUS: The Social Responsibility of Business: Who Are the Responsible Agents", Business Ethics: A European Review, vol. 5, no. 2, pp. 81-86.

Kyong-Song, R., Hammond, J.O.S., Chol-Nam, K., Hyok, K., Yong-Gun, Y., Gil-Jong, P., Chong-Song, R., Oppenheimer, C., Liu, K.W., Iacovino, K., and Kum-Ran, R. (2016), "Evidence for partial melt in the crust beneath Mt. Paektu (Changbaishan), Democratic People's Republic of Korea and China”, Science Advances, Vol. 2 No. 4, e1501513.

Kurbalija, J. and Katrandjiev, V. (Eds.) (2006), Multistakeholder Diplomacy - Challenges and Opportunities DiploFoundation, Msida, Malta.

Lewis, J. (1999) Development in Disaster-Prone Places: Studies of vulnerability, Intermediate Technology Publications, London.

Leogrande, W.M. (2015), "Normalizing US-Cuba relations: escaping the shackles of the past”, International Affairs, Vol. 91 No. 3, pp. 473-488.

Martin, B. (1979), The bias of science, Society for Social Responsibility in Science, Canberra.

Morison, W.L. (1948), "A Re-Examination of the Duty Of Care", The Modern Law Review, Vol. 11, pp. 9-35.

Naranjo-Diaz, L. (2000), "Cuba", in Glantz, M.H. (Ed.), Once burned, twice shy? Lessons learned from the 1997-98 El Niño, United Nations University Press, Tokyo, pp. 67-77.

Naranjo-Diaz, L. (2002), "La Niña's impacts in Cuba: The opposite side of the coin?", in Glantz, M.H. (Ed.), La Niña and its impacts: Facts and speculation, United Nations University Press, Tokyo, pp. 139-145.

Patt, A.G., Ogallo, L, and Hellmuth, M. (2007), "Learning from 10 Years of Climate Outlook Forums in Africa", Science, vol. 318, pp. 49-50.

Platt, T. (1988), "Cuba and the Politics of Human Rights", Social Justice, Vol. 15 No. 2, pp. $38-54$.

Price, D. (2000), "Anthropologists as Spies", The Nation, 20 November 2000, https://www.thenation.com/article/anthropologists-spies

Research Council of Norway (2009), Norwegian Programme for Research Cooperation with China (CHINOR), Research Council of Norway, Oslo.

Schultz, C.H. (2012), "Altering the Standard of Care in Disasters-Unnecessary and Dangerous", Annals of Emergency Medicine, Vol. 59 No. 3, 191-195. 
Sending, O.J., Pouliot, V., and Neumann, I.B. (2011), "The Future of Diplomacy: Changing Practices, Evolving Relationships”, International Journal, Vol. 66 No. 3, pp. 527-542

Sims, H. and Vogelmann, K. (2002), "Popular Mobilization and Disaster Management in Cuba", Public Administration and Development, Vol. 22 No. 5, pp. 389-400.

Smith III, F.L. (2014), "Advancing science diplomacy: Indonesia and the US Naval Medical Research Unit”, Social Studies of Science, Vol. 44 No. 6, pp. 825-847.

Sokol, D.K. (2006), "Virulent Epidemics and Scope of Healthcare Workers' Duty of Care", Emerging Infectious Diseases, Vol. 12 No. 8, pp. 1238-1241.

Stone, R. (2011), "Vigil at North Korea's Mount Doom”, Science, Vol. 334 No. 6056, 584588 .

Stone, R. (2013), “Sizing Up a Slumbering Giant”, Science, Vol. 341 No. 6150, pp. 10601061.

Tavares, R. (2009), Paradiplomacy: Cities and States as Global Players, Oxford University Press, New York, NY.

Tonami, A. (2016), Asian Foreign Policy in a Changing Arctic, Palgrave Macmillan, London.

Turekian, V.C. and Wang, T.C. (2014), "Educating for Science Diplomacy", Science \& Diplomacy, Vol. 3 No. 1, http://www.sciencediplomacy.org/editorial/2014/educating-forscience-diplomacy

University of Auckland (2016), "New earthquake resilient technology for buildings receives MBIE funding", University of Auckland Press release, 14 September 2016, https://www.auckland.ac.nz/en/about/news-events-and-notices/news/news-2016/09/newearthquake-resilient-technology-for-buildings-mbie-funding.html

USC Center on Public Diplomacy (2010), Science Diplomacy and the Prevention of Conflict: Proceedings of the USC Center on Public Diplomacy Conference February 4-5, 2010, compiled by Matthew R. Wallin, USC (University of Southern California) Center on Public Diplomacy at the Annenberg School, Los Angeles, CA.

Vanc, A.M. and Fitzpatrick, K.R. (2016), "Scope and status of public diplomacy research by public relations scholars, 1990-2014”, Public Relations Review, Vol. 42 No. 3, pp. 432-440.

Yeats, R.S. (2014), "Partnering with Cuba: Earthquake hazards", Science, Vol. 345 No. 6194, p. 278.

Yu, S., Yoon, S.M., Choi, E.-K., Kim, S.-D., Lee, Y.-J., Lee, Y., and Choi, K.-H. (2016), "Quantitative assessment of national resilience: A case study of Mount Paektu eruption scenarios on South Korea", International Journal of Disaster Risk Reduction, Vol. 19 October, pp. 118-132.

Wisner, B., Blaikie, P., Cannon, T., and Davis, I. (2004), At Risk: Natural hazards, people's vulnerability and disasters, Routledge, London. 
Yim, E.S., Callaway, D.W., Fares, S., and Ciottone, G.R. (2009) "Disaster Diplomacy: Current Controversies and Future Prospects", Prehospital and Disaster Medicine, Vol. 24 No. 4, pp. 291-293.

Ziegler, C.E. (1990), Environmental Policy in the USSR, University of Massachusetts Press, Amherst, MA. 